\title{
Short communication: An overview of the trematodes fauna of pool frog Pelophylax lessonae (Camerano, 1882) in the Volga Basin, Russia: 2. Larval stages
}

\author{
IGOR V. CHIKHLYAEV ${ }^{1}$, ALEXANDER B. RUCHIN ${ }^{2, \vartheta}$, ALEXANDER I. FAYZULIN ${ }^{1}$ \\ ${ }^{1}$ Institute of Ecology of the Volga Basin, Russian Academy of Sciences, Togliatti, Russia \\ 2 Joint Directorate of the Mordovia State Nature Reserve and National Park "Smolny", Saransk, Russia \\ "email: sasha_ruchin@ rambler.ru, ruchin_mgpz@mail.ru. Tel.: +50-8001010010; Fax.: +50-7001010062.
}

Manuscript received: 16 November 2018. Revision accepted: 15 May 2019.

\begin{abstract}
Chikhlyaev IV, Ruchin AB, Fayzulin AI. 2019. Short communication: An overview of the trematodes fauna of the pool frog Pelophylax lessonae (Camerano, 1882) in the Volga Basin, Russia: 2. Larval stages. Nusantara Bioscience 11: 106-111. This paper presents data on the trematodes fauna of the pool frog Pelophylax lessonae (Camerano, 1882) from 13 regions of the Volga Basin. It consolidates data from different authors over the past 30 years, supplemented by our own research results. There are authentically known findings of 10 trematodes species at the larval stage of development. The species Codonocephalus urniger (Rudolphi, 1819), mtc., Neodiplostomum spathoides Dubois, 1937, mtc. and Pharyngostomum cordatum (Diesing, 1850), mtc. have been observed for the first time in the given host on the territory of Russia and Volga basin. For each species of trematodes, there is the following information is included: taxonomic position, localization, area of detection, biology, definitive hosts, geographic distribution and degree of hostspecificity.
\end{abstract}

Keywords: Larval stages, Pelophylax lessonae, pool frog, trematodes, Volga Basin

\section{INTRODUCTION}

Amphibians play a significant role in the coastal (nearwater) biocoenosis. Being a common small predator and also a food object at the same time, they serve as an important intermediary element in the process of transferring substance and energy from the invertebrates of lower trophic level to the predatory vertebrates of the higher trophic levels. In parallel with this, as an intercalary, additional and/or reservoir host, the amphibians circulate through the trophic relations of different helminth species, including those that are pathogenic in animals and humans. Being parasitic on frogs, the larval stages of helminths indicate the presence/absence of particular predator species in a given biocoenosis, and may serve as bioindicators of the degree of anthropogenic environmental transformation, in both rural and urban ecosystems. The pool frog Pelophylax lessonae (Camerano, 1882) is one of the most commonly occurring and numerous forest amphibians. It lives in shallow, standing and overgrown pools in the lowland broadleaved and mixed forests of Europe, where it is one of the main components of the diet of snakes, mustelids and large amphibians (cannibalism). In addition, it is has been noted in the diet of pikes, European pond turtles, various near-water inhabitants, storks, diurnal birds of prey and owls, rodents, insectivorous and canine mammals (Kuzmin 2012; Sainsbury et al. 2017; Korzikov and Aleksanov 2018).

The wide range of predators that consuming the pool frog are also consuming the larval stages of parasitic the helminths (trematodes), which then develop through a change in hosts. The trematode has been studied in the territory of the pool frog's habitat in a narrow range of countries: Poland (Grabda-Kazubska 1972; Popiolek et al. 2011), the former Czechoslovakia (Vojtkova 1974; Vojtkova and Vojtek 1975), modern Serbia (Bjelic-Cabrilo et al. 2009), Belarus (Shimalov 2002, 2008, 2009) and Ukraine (Volgar-Pastukhova 1959; Mazurmovich 1965; Maguza 1973). Data from the last century is reflected in a consolidated work on the trematodes in frogs and toads of the European countries (Vojtkova and Roca 1994). It should be noted that the discovery of hybrid speciation within the population system of the Pelophylax esculentus complex and the difficulties associated with the species diagnostics of green frogs have complicated the study of their helminths (Cavlovic et al. 2018; Fayzulin et al. 2018). In Russia, the combined information on the trematodes fauna of the pool frog was presented in a single general summary (Ryzhikov et al. 1980) and later in two regional ones (Chikhlyaev et al. 2012a, b).

This article is part of a series included into a cycle of publications on the modern character of a helminth fauna from amphibians of the Volga Basin (Ruchin et al. 2009, 2016; Reshetnikov et al. 2013; Chikhlyaev and Ruchin 2014; Chikhlyaev et al. 2016b). The aim of the study was to present a review of the fauna of the larval stages of trematodes of pool frogs from Volga Basin populations on the basis an analysis of literature sources analysis and our own research. 


\section{MATERIALS AND METHODS}

In the period from 1936 to 2016, many authors had examined 1,460 specimens of pool frog from 13 regions of the Volga basin, among which are: Kaluga, Moscow, Ivanovo, Kostroma, Nizhny Novgorod, Tambov, Ulyanovsk and Samara regions, the Republics of Mordovia, Chuvashia, Mari El, Tatarstan and Bashkortostan. For species determination of trematodes, we used reports of Ryzhikov et al. (1980). At distribution on taxons adhered to the modern data on systematics of trematodes (Tkach et al. 1999, 2000, 2001; Olson et al. 2003; Keys to the Trematoda 2002, 2008) and given the website "Fauna Europaea" (http://www.fauna-eu.org).

\section{RESULTS AND DISCUSSION}

In the pool frog population of the Volga Basin, there are 10 registered species of trematodes in the larval stage of development, belonging to eight genera, four families and two orders (Table 1). Three species of trematodes are indicated for the first time from this host in this basin: Codonocephalus urniger (Rudolphi, 1819), mtc., Neodiplostomum spathoides (Dubois, 1937), mtc. and Pharyngostomum cordatum (Diesing, 1850), mtc. All 10 species of trematodes were found only in the larval stage, so they are using the amphibians as intercalary (mesocercaria), intermediate (metacercaria) and/or reservoir (parathenic) hosts. Of these, eight species are broadly specific, polyhostal parasites of anurans whilst two (C. urniger, mtc., N. spathoides, mtc.) are specific, oligohostal for the Family Ranidae.

Below is an annotated list of pool frog trematodes species, including their systematic position, localization, areas of detection, biology and geographic distribution. Also, information on the degree of parasites hostspecificity is provided. In addition, for each species of helminths, a list of their definitive hosts within Russia is indicated, corrected according to an analysis of the literature, including Ryzhikov et al. (1980); Sudarikov et al. (2002); Kostyunin (2010); Chikhlyaev et al. (2012a,b); Kirillov et al. (2012, 2018); Kuzmin (2012).

Class: Trematoda (Rudolphi, 1808)

Order: Plagiorchiida (La Rue, 1957)

Family: Leptophallidae (Dayal, 1938)

Paralepoderma cloacicola (Luhe, 1909), mtc.

Localization: Kidneys.

Areas of detection: The region of Nizhny Novgorod, Tambov and Samara regions, the Republics of Chuvashia and Tatarstan.

Biology: Metacercariae of this species: widely specific parasites of amphibians. Trixenic life cycle. Intermediate hosts: gastropod mollusks genera Planorbis and Planorbarius (Dobrovolsky 1969; Grabda-Kazubska 1975), definitive hosts: grass and dice snakes.
Definitive hosts: Serpentes (Natrix natrix (Linnaeus, 1758), Natrix tessellata (Laurenti, 1768), Vipera renardi (Christoph, 1861) (rarely)).

Distribution: Palearctic.

Order: Strigeida (La Rue, 1926)

Family: Strigeidae (Railliet, 1919)

Strigea falconis (Szidat, 1928), mtc.

Localisation: Musculature.

Areas of detection: Samara region and the Republic of Tatarstan.

Biology: Meso- and metacercariae stage it is a specific parasite of anurans Family Ranidae. Tetraxenic life cycle. Intermediate host is a gastropod mollusks genus Planorbis. Adult stages complete development in the intestine of diurnal birds of prey (Odening 1967).

Definitive hosts: Falconiformes (Pandion haliaetus (Linnaeus, 1758), Haliaeetus albicilla (Linnaeus, 1758), Falco subbuteo (Linnaeus, 1758), Falco tinnunculus (Linnaeus, 1758), Accipiter nisus (Linnaeus, 1758), Accipiter gentilis (Linnaeus, 1758), Accipiter brevipes (Severtzov, 1850), Aquila chrysaetos (Linnaeus, 1758), Aquila clanga (Pallas, 1811), Buteo buteo (Linnaeus, 1758), Buteo lagopus (Pontoppidan, 1763), Circus aeruginosus (Linnaeus, 1758), Milvus migrans (Boddaert, 1783)).

Distribution: Cosmopolitan.

Strigea sphaerula (Rudolphi, 1803), mtc.

Syn.: Tetracotyle crystallina (Rudolphi, 1819), mtc.

Syn.: Tetracotyle sphaerula (Rudolphi, 1803), mtc.

Localization: Serous coat of inner organs, pericardium, musculature.

Areas of detection: Regions of Nizhny Novgorod and Samara regions, the Republic of Mordovia.

Biology: Meso- and metacercariae of this species: widely specific parasite of anurans. Tetraxenic life cycle. Intermediate hosts: gastropod mollusks genera Planorbis, Anisus, and Segmentina. Definitive hosts: corvids (Odening 1966a, 1967).

Definitive hosts: Corvidae (Corvus cornix (Linnaeus, 1758), Pica pica (Linnaeus, 1758), Corvus monedula (Linnaeus, 1758), Corvus frugilegus (Linnaeus, 1758); Columba livia (Gmelin, 1789), Anas platyrhynchos (Linnaeus, 1758), Buteo buteo (sporadically)). Distribution: Europe.

Strigea strigis (Schrank, 1788), mtc.

Syn.: Tetracotyle strigis (Schrank, 1788), mtc.

Syn.: Tetracotyle colubri (Linstow, 1877), mtc.

Localization: Serous coat of inner organs, mesentery, musculature.

Areas of detection: Regions of Kaluga, Nizhny Novgorod and Samara regions, the Republics of Mordovia, Chuvashia, and Tatarstan.

Biology: Meso- and metacercariae stage it is a widely specific parasite of anurans. Tetraxenic life cycle. Intermediate host is a gastropod mollusks genus Planorbis. Definitive hosts: owls (Odening 1966b, 1967). 
Definitive hosts: Strigidae (Bubo bubo (Linnaeus, 1758), Asio otus (Linnaeus, 1758), Asio flammeus (Pontoppidan, 1763), Strix aluco (Linnaeus, 1758), Strix uralensis (Pallas, 1771), Athene noctua (Scopoli, 1769), Tyto alba (Scopoli, 1769)); and rarely Falconiformes

Distribution: Palearctic.

Family: Diplostomidae (Poirier, 1886)

Codonocephalus urniger (Rudolphi, 1819), mtc.

Localization: Body cavity, serous coat of internal organs, adipose bodies, musculature.

Area of detection: Samara region. First discovered in the pool frog of the fauna of Russia and the Volga Basin.

Biology: Metacercariae of this species it is a specific parasite of green frogs (gen. Pelophylax). Trixenic life cycle. Intermediate hosts are gastropod mollusks genus Lymnaea. Adult stages parasitize in the intestine of longlegged wading birds (Niewiadomska 1964).

Definitive hosts: Ciconiiformes (Botaurus stellaris (Linnaeus, 1758), Ixobrychus minutus (Linnaeus, 1766), Ardea cinerea (Linnaeus, 1758)).

Distribution: Palearctic.

Neodiplostomum spathoides (Dubois, 1937), mtc.

Syn.: Neodiplostomulum minor (Dubinina, 1950), mtc.

Syn.: Neodiplostomulum cochleare (Krause, 1914), mtc.

Localization: Musculature, body cavity, subcutaneous tissue.

Area of detection: Samara region. First discovered in the pool frog of the fauna of Russia and the Volga Basin.

Biology: At this stage it is a specific parasite in green frogs. Trixenic life cycle. Intermediate hosts are a gastropod mollusks genera Planorbis and Planorbarius. Definitive hosts are diurnal birds of prey (Sudarikov 1960a; Odening 1965a, b).

Definitive hosts: Falconiformes (Pernis apivorus (Linnaeus, 1758), A. clanga, B. buteo, C. aeruginosus, $M$. migrans, Falco vespertinus (Linnaeus, 1766), $F$. tinnunculus, $P$. haliaetus, $H$. albicilla).

Distribution: Palearctic.

Tylodelphys excavata (Rudolphi, 1803), mtc

Syn.: Tylodelphys rhachiaea (Henle, 1895), mtc.

Localisation: spinal cord canal.

Areas of detection: Moscow, Nizhny Novgorod and Samara regions, the Republics of Mordovia and Tatarstan.

Biology: Metacercariae of a trematode it is a specific parasite of anurans family Ranidae. Trixenic life cycle. Intermediate hosts are gastropod mollusks genera Planorbis and Coretus. Adult stages complete their development in the intestines of long-legged wading birds (Sudarikov 1960a).

Definitive hosts: Ciconiiformes (A. cinerea, Nycticorax nycticorax (Linnaeus, 1758), B. stellaris, I. minutus).

Distribution: Palearctic.
Alaria alata (Goeze, 1782), msc.

Localisation: Musculature, mesentery, serous coat of the internal organs.

Areas of detection: Region of Nizhny Novgorod, Tambov, Ulyanovsk and Samara regions, the Republics of Mordovia, Chuvashia and Tatarstan.

Biology:Mesocercariae stage: widely specific parasite of anurans. Trixenic life cycle. Intermediate hosts: gastropod mollusks of genera Planorbis and Anisus. Definitive hosts: canids (Sudarikov 1959, 1960b).

Definitive hosts: Canidae (Nyctereutes procyonoides (Grey, 1834), Canis lupus (Linnaeus, 1758), Vulpes vulpes (Linnaeus, 1758)).

Distribution: Cosmopolitan.

Pharyngostomum cordatum (Diesing, 1850), mtc.

Syn.: Neodiplostomulum major (Dubinina, 1950), mtc.

Syn.: Neodiplostomulum spathoides (Dubois, 1937), mtc.

Localization: Musculature, mesentery, pericardium, body cavity, stomach and intestinal walls.

Area of detection: Samara region. First discovered in the pool frog of the fauna of Russia and the Volga Basin.

Biology: Metacercariae of this species it is a specific parasite of green frogs. Trixenic life cycle. Intermediate host is a gastropod mollusks genus Planorbis. Adult stages - intestines of wild and domesticated carnivores (Sudarikov 1960b; Sudarikov et al. 1991).

Definitive hosts: Canidae (N. procyonoides, V. vulpes, C. lupus), Felidae (Felis silvestris (Schreber, 1775)).

Distribution: Palearctic.

Incertae sedis group

Family: Encyclometridae (Mehra, 1931)

Encyclometra colubrimurorum (Rudolphi, 1819), mtc.

Syn.: Encyclometra natricis (Baylis and Cannon, 1924), mtc.

Localization: Body cavity, serous coat of internal organs (liver, spleen, ovaries), mesentery.

Areas of detection: Region of Tambov, Ulyanovsk and Samara regions, the Republic of Tatarstan.

Biology: Metacercariae stage it is a specific parasite of anurans families Ranidae and Pelobatidae. Life cycle not completely studied. Intermediate hosts: are unknown. Adult stages parasitize in the gullets and stomachs of grass and dice snakes, and rarely in vipers (Sharpilo 1976).

Definitive hosts: Serpentes (N. natrix, N. tessellata, Vipera berus (Linnaeus, 1758), and rarely $V$. renardi (rarely)).

Distribution: Palearctic.

The largest number of quantity species of trematodes (10) was registered in pool frogs in the Samara (10 species) region. Average numbers were recorded in the Republics of Tatarstan (six) and Mordovia (four), and the Nizhny Novgorod region (five). The least numbers were found in the Tambov region and the Republic of Chuvashia (both three), and the Ulyanovsk (two), Moscow and Kaluga (one each) regions. The larval stages of trematodes in pool frogs 
in the Ivanovo and Kostroma regions, and the Republics of Mari El and Bashkortostan, were not registered (Table 1).

These differences are of a biotopic nature, depending on the conditions of the habitat and the diversity of the amphibians in a particular biotope, each of which is characterized by its own historically-related complex of abiotic and biotic factors. On the other hand, the distributions could also be due to geographical location, level of anthropogenic impact and the difference in size of the amphibian samplings.

The trematodes faunas of the pool frog vary significantly in the Volga Basin. Of the registered 10 species, not all were noted in all regions. The trematode of A. alata, msc. found in seven regions of 13 locations examined, was the most often found. One species ( $S$. strigis, mtc.) was detected in six regions, two species $(P$. cloacicola, mtc., T. excavata, mtc.) in five and one (E. colubrimurorum, mtc.) in four regions. The other species are seldom seen in this host. In particular, S. falconis, mtc., C. urniger, mtc. N. spathoides, mtc. and Ph. cordatum, mtc. were found locally and they were observed in one or two regions (Table 1).
The helminth faunas in the amphibians are closely connected to their way of life and are formed depending on biotopic timing, the duration of their stay in the water and the food spectrum. Pool frog helminths composition in the Volga Basin are more than $25 \%$ represented by trematode larval stages (10 species). Their development proceeds in five types and two subtypes in two life cycles groups. Most circulates on trixenic (six types); less on tetraxenic (three), cycles. This indicates a wide array of definitive hosts involved in the circulation of the parasites, including snakes (two species), owls (one), corvids (one), diurnal birds of prey (two) and long-legged wading birds (two), and canids (two). This species of amphibians plays a significant role in the transfer of the mesocercariae and metacercariae of trematodes to their reservoir hosts (common and marsh frogs, common toads, vipers, pond turtles, ducks and gulls, rodents, mustelids and insectivores, wild boars). All this points to the importance of the pool frog as valuable food resources in the ration of predators of a higher trophic level in the natural biocoenosis of the Volga basin.

Table 1. Trematode larval stages in the pool frog Pelophylax lessonae in the Volga basin regions

\begin{tabular}{|c|c|c|c|c|c|c|c|c|c|c|c|c|c|}
\hline Trematodes species & KL & MS & IV & KS & $\mathbf{N N}$ & TM & UL & SM & $\mathbf{R M}$ & CH & ME & TT & BS \\
\hline \multicolumn{14}{|c|}{$\begin{array}{l}\text { Class Trematoda (Rudolphi, 1808) } \\
\text { Order Plagiorchiida (La Rue, 1957) } \\
\text { Family Leptophallidae (Dayal, 1938) }\end{array}$} \\
\hline Paralepoderma cloacicola, mtc. & & & & & + & + & & + & & + & & + & \\
\hline \multicolumn{14}{|c|}{$\begin{array}{c}\text { Order Strigeida (La Rue, 1926) } \\
\text { Family Strigeidae (Railliet, 1919) }\end{array}$} \\
\hline Strigea falconis, mtc. & & & & & & & & + & & & & + & \\
\hline Strigea sphaerula, mtc. & & & & & + & & & + & + & & & & \\
\hline Strigea strigis, mtc. & + & & & & + & & & + & + & + & & + & \\
\hline \multicolumn{14}{|c|}{ Family Diplostomidae (Poirier, 1886) } \\
\hline Codonocephalus urnigerus, mtc. & & & & & & & & + & & & & & \\
\hline Neodiplostomum spathoides, mtc. & & & & & & & & + & & & & & \\
\hline Tylodelphys excavata, mtc. & & + & & & + & & & + & + & & & + & \\
\hline $\begin{array}{l}\text { Alaria alata, msc. } \\
\text { Pharyngostomum cordatum, mtc. }\end{array}$ & & & & & + & + & + & $\begin{array}{l}+ \\
+\end{array}$ & + & + & & + & \\
\hline
\end{tabular}

Incertae sedis group

Family Encyclometridae (Mehra, 1931)

Encyclometra colubrimurorum, mtc.

Total number of species

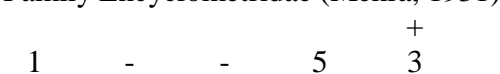

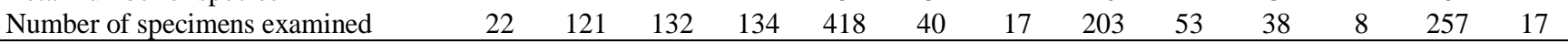

Note: KL: Kaluga region (Chikhlyaev et al. 2016a); MS: Moscow region (Kotova 1936); IV: Ivanovo region (Kirillova 2002; Kirillova and Egorov 2002); KS: Kostroma region (Radchenko and Budalova 1980); NN: Nizhny Novgorod region (Borisova 1988; Nosova 1983, 1985, 1990, 1993; our data); TM: Tambov region (Rezvantseva and Chikhlyaev 2005; Kolodina et al. 2016); UL: Ulyanovsk region (Indiryakova et al. 2008); SM: Samara region (Evlanov et al. 2001, 2002; Chikhlyaev 2004, 2009, 2017; Fayzulin et al. 2013; Kirillov et al. 2018; our data); RM: Republic of Mordovia (Chikhlyaev et al. 2015; Ruchin et al. 2016; our data); CH: Republic of Chuvashia (Chikhlyaev and Fayzulin 2015; our data); ME: Republic of Mari El (our data); TT: Republic of Tatarstan (Smirnova 1968, 1970; Smirnova and Sizova 1978; Smirnova et al. 1987; Shaldybin 1974, 1977; our data); BS: Republic of Bashkortostan (Ayupov et al. 1974; Bayanov 1992; Yumagulova 2000). 


\section{ACKNOWLEDGEMENTS}

This study was conducted with the support of a grant Russian Foundation for Basic Research 14-04-97031 r_povolzhje_a.

\section{REFERENCES}

Ayupov KV, Valiullin SM, Khaziev GZ, Bayanov MG, Kazadaev VI, Antonov PP. 1974. Helminths of animals, humans and plants in the Bashkir ASSR. In: Helminths of Animals, Humans and Plants in the Southern Urals. Issue 1. Institute of Biology of the Bashkir branch Academy of Sciences of the USSR, Ufa. [Russian]

Bayanov M. 1992. Helminths of amphibians in Bashkortostan. Probl Anim Ecol Southern Ural (5): 2-10.

Bjelic-Cabrilo O, Popovic E, Paunovic A. 2009. Helminthofauna of Pelophylax kl. esculentus (Linne, 1758) from Petrovaradinski Rit Marsh (Serbia). Helminthologia 46 (2): 107-111.

Borisova VI. 1988. Helminths of amphibians geographical distribution study. Parazitologiya 22 (6): 471-475

Cavlovic K, Buj I, Karaica D, Jelic D, Choleva L. 2018. Composition and age structure of the Pelophylax esculentus complex (Anura; Ranidae) population in inland Croatia. Salamandra 54 (1): 11-20.

Chikhlyaev IV, Fayzulin AI. 2015. Materials on the helminth fauna of the Pool frog Pelophylax lessonae (Camerano, 1882) in the Chuvash Republic. Sci Pap Prisursky State Nat Reserve 30 (1): 276-279.

Chikhlyaev IV, Kirillov AA, Kirillova NY. 2012a. Trematodes (Trematoda) of amphibians (Amphibia) of the Middle Volga region. 1. Orders Fasciolida, Hemiurida, Paramphistomida and Strigeida. Parazitologiya 46 (3): 171-192.

Chikhlyaev IV, Kirillov AA, Kirillova NY. 2012b. Trematodes (Trematoda) of amphibians (Amphibia) of the Middle Volga region. 2. Order Plagiorchiida. Parazitologiya 46 (4): 290-313.

Chikhlyaev IV, Ruchin AB. 2014. The helminth fauna study of European common brown frog (Rana temporaria Linnaeus, 1758) in the Volga basin. Acta Parasitol 59 (3): 459-471.

Chikhlyaev IV, Korzikov VA, Fayzulin AI. 2016a. Materials for the helminth fauna of the Pool frog Pelophylax lessonae and the Common toad Bufo bufo (Amphibia, Anura) in Kaluga region. Bull Samara Sci Cent Russ Acad of Sci 5 (2): 377-381.

Chikhlyaev IV, Ruchin AB, Fayzulin AI. 2015. Helminths of tailless amphibians (Anura, Amphibia) of the Mordovia Reserve. Proc Mordovia State Nat Reserve 14: 376-388.

Chikhlyaev IV, Ruchin AB, Fayzulin AI. 2016b. The helminth fauna study of European common toad in the Volga basin. Nat Environ Pollut Technol 15 (3): 1103-1109.

Dobrovolsky AA. 1969. The life cycle of Paralepoderma cloacicola (Luhe, 1909) Dollfus, 1950 (Trematoda, Plagiorchiidae). Bull Leningrad Univ 9: 28-38.

Evlanov IA, Kirillov AA, Chikhlyaev IA, Guzova NY, Zhiltsova LV. 2001. Parasites of vertebrates of the Samara region. Part 1: A systematic catalog. Institute of Ecology of the Volga River Basin RAS, Togliatti.

Evlanov IA, Kirillov AA, Chikhlyaev IA, Guzova NY, Zhiltsova LV 2002. Parasites of vertebrates of the Samara region. Part 2: Distribution of parasites by hosts. Institute of Ecology of the Volga River Basin RAS, Togliatti.

Fayzulin AI, Chikhlyaev IV, Kuzovenko AE. 2013. Amphibians of the Samara region: Monograph. Cassandra Publ, Togliatti.

Fayzulin AI, Zamaletdinov RI, Litvinchuk SN, Rosanov Ju.M, Borkin LJ, Ermakov OA, Ruchin AB, Lada GA, Svinin AO, Bashinsky IV Chikhlyaev IV. 2018. Species composition and distributional peculiarities of green frogs (Pelophylax esculentus complex) in Protected Areas of the Middle Volga Region (Russia). Nat Conserv Res 3 (Suppl.1): 1-16. DOI: 10.24189/ncr.2018.056

Grabda-Kazubska B. 1972. Pasozyty plazów i gadów. Katalog Fauny Pasozytniczej Polski. Warszawa-Wroclaw, Poland.

Grabda-Kazubska B. 1975. A study of the trematode genus Paralepoderma Dollfus, 1950 (Trematoda: Plagiorchiidae). Acta Parasitol Polon 23: 463-484.
Indiryakova TA, Romanova EM, Matveeva EA. 2008. Helminth fauna species diversity of amphibians in the Ulyanovsk region. Proc OGAU 1 (17): 172-176

Keys to the Trematoda (Eds Gibson DI, Jones A, Bray RA). 2002. Vol 1. CABI Publishing Wallingford, UK. and The Natural History Museum, London

Keys to the Trematoda (Eds Bray RA, Gibson DI, Jones A). 2008. Vol 3. CABI Publishing Wallingford, UK. and The Natural History Museum, London.

Kirillov AA, Kirillova NY, Chikhlyaev IV. 2012. Trematodes of land vertebrates of the Middle Volga region: Monograph. Cassandra Publ, Togliatti.

Kirillov AA, Kirillova NY, Chikhlyaev IV. 2018. Parasites of vertebrate animals of the Samara region: Monograph. Poliar, Togliatti.

Kirillova YA. 2002. Helminth fauna of tailless amphibians of the order Anura in Central Non-Chernozem Zone of Russian Federation. [Dissertation]. Ivanovo State University, Ivanovo. [Russia]

Kirillova YA, Egorov SV. 2002. Helminth fauna of tailless amphibians of the Ivanovo region. In: Theory and Practice of Fight Against Parasitic Diseases (Zoonoses); Materials of a Scientific Conference. Vol 3. Moscow. [Russian]

Kolodina AS, Pyatova MV, Ravkovskaya EA, Lada GA. 2016. To the question of nutrition and helminths of the Pool frog (Pelophylax lessonae) in the conditions of Tambov region. Bulletin Tambov University. Ser Nat Technol Sci 21 (5): 1791-1796.

Korzikov VA, Aleksanov VV. 2018. On some factors driving the presence of amphibians in water bodies of the Upper Oka Basin (Central Russia). Nat Conserv Res 3 (Suppl. 1): 110-119.

Kostyunin VM. 2010. Helminth fauna of terrestrial vertebrates of the Middle Povolzhie: Monograph. NGPU Publishing, Nizhny Novgorod.

Kotova EN. 1936. Parasitic worms of fish and amphibians of the Klyazma river in the area of the Bolshevo Biological Station. Notes Bolshevo Biol Stn 9: 139-140.

Kuzmin SL. 2012. Amphibians of the former USSR. 2nd eds. Association of scientific editions KMK, Moscow.

Maguza VS. 1973. Helminths of amphibians in Ukrainian Polesye. [Dissertation]. Kyiv University, Kyiv.

Mazurmovich BN. 1965. Parasitic worms of amphibians of the Soviet Carpathians and adjacent areas. Parasites and parasitoses of humans and animals: Republics inter-department collection of research papers, Kyiv.

Niewiadomska K. 1964. The life cycle of Codonocephalus urnigerus (Rudolphi, 1819): Strigeidae. Acta Parasitol Polon 12: 283-296.

Nosova KF. 1983. Helminths of tailless amphibians in green space of Gorky city. Fauna, taxonomy, biology and ecology of helminths and their insert hosts, Gorky.

Nosova KF. 1985. To the study of lakes origin and zonality influence of the on the helminth fauna of the Pool frog. Helminths and their intermediate hosts: Intercollege collection of scientific papers, Gorky.

Nosova KF. 1990. Helminths of anurans in lake ecosystems of the middle belt of the European part of the RSFSR. [Dissertation]. Gorky State Pedagogical University, Gorky, USSR.

Nosova KF. 1993. Helminth fauna of the Pool frog in Nizhny Novgorod region. Publishing House of NSPI, Nizhny Novgorod. Chief department of VINITI, No. 2038-B93.

Odening K. 1965a. Der Lebenszyklus von Neodiplostomum spathoides Dubois (Trematoda, Strigeida) im Raum Berlin nebst Baitragen zur Entwicklungsweise verwandter Arten. Zool Yahrb Syst 92: 523-624.

Odening K. 1965b. Die Lebenszyklen der Trematoda Neodiplostomum spathoides Dubois und N. attenuatum (v. Linstow) im Raum Berlin. Monatsber Deutsch Acad Wissensch zu Berlin 7: 952-954

Odening K. 1966a. Der Lebenszyklus des Trematoden Strigea sphaerula (Rudolphi) im Raum Berlin. Monatsber Deutsch Acad Wissensch zu Berlin 8: 695-696.

Odening K. 1966b. Der Lebenszyklus des Trematoden Strigea strigis (Schrank) im Raum Berlin. Monatsber Deutsch Acad Wissensch zu Berlin 8: 696-697.

Odening K. 1967. Die lebenszyklen von Strigea falconispalumbi (Viborg), S. strigis (Schrank) und $S$. sphaerula (Rudolphi) (Trematoda, Strigeida) im Raum Berlin. Zool Yahrb Syst 94: 1-67.

Olson PD, Cribb TH, Tkach VV, Bray RA, Littlewood DTJ. 2003. Phylogeny and classification of the Digenea (Platyhelminthes: Trematoda). Int J Parasitol 33: 733-755.

Popiolek M, Rozenblut-Koscisty B, Kot M, Nosal W, Ogielska M. 2011. Endoparasitic helminths of water frog complex in Poland: do differences exist between the parental species Pelophylax ridibundus 
and Pelophylax lessonae, and their natural hybrid Pelophylax esculentus? Helminthologia 48 (2): 108-115.

Radchenko NM, Budalova TM. 1980. Helminths of amphibians in Kostroma region. IX Conference of Ukrainian Parasitological Society. Part 3. Kiev: 179-181.

Reshetnikov AN, Sokolov SG, Chikhlyaev IV, Fayzulin AI, Kirillov AA, Kuzovenko AE, Protasova EN, Skomorokhov MO. 2013. Direct and indirect interactions between an invasive alien fish (Perccottus glenii) and two native semi-aquatic snakes. Copeia 1: 103-110.

Rezvantseva MV, Chikhlyaev IV. 2005. About helminths of green frogs in Tambov region. Actual problems of herpetology and toxicology: Collection of research papers. Issue 8. Institute of Ecology of the Volga River Basin RAS, Togliatti.

Ruchin AB, Chikhlyaev IV, Lukijanov SV. 2009. Analysis of helminthofauna of Common spaedfoot Pelobates fuscus (Laurenti, 1768) and Moor frog Rana arvalis Nilsson, 1842 (Amphibia: Anura) at their joint habitation. Parazitologiya 43 (3): 240-247.

Ruchin AB, Kirillov AA, Chikhlyaev IV, Kirillova NY. 2016. Parasitic worms of land vertebrates in Mordovia Reserve (annotated list of species). Moscow.

Ryzhikov KM, Sharpilo VP, Shevchenko NN. 1980. Helminths of amphibian fauna of the USSR. Nauka Publ, Moscow.

Sainsbury AW, Yu-Mei R, Agren E, Vaughan-Higgins RJ, Mcgill IS Molenaar F, Peniche G, Foster J. 2017. Disease risk analysis and post-release health surveillance for a reintroduction programme: the Pool frog Pelophylax lessonae. Transb Emerg Dis 64 (5): 1530-1548.

Shaldybin SL. 1974. The role of anurans in coastal biogeocoenosis. [PhD Abstract]. Kazan State University, Kazan, USSR.

Shaldybin SL. 1977. To the parasitic fauna of anurans in Volga-Kama Nature Reserve. In: Questions of Herpetology. Nauka, Leningrad.

Sharpilo VP. 1976. Parasitic worms of reptiles of USSR fauna. Naukova Dumka Publ, Kyiv.

Shimalov VV. 2002. Helminth fauna of amphibians of open channels in meliorated regions of the Belorussian Polesie. Parazitologiya 36 (4): 304-309.

Shimalov VV. 2008. Helminth fauna of amphibians (Vertebrata, Amphibia) and reptiles (Vertebrata, Reptilia) in the landscape wildlife area "Bugsky"' (Republic of Belarus). Bull Brest Univ 2 (31): 80-87.

Shimalov VV. 2009. Helminth fauna of amphibians (Vertebrata: Amphibia) in the Republic of Belarus. Parazitologiya 43 (2): 118-129.

Smirnova MI. 1968. To the helminth fauna of amphibians of the Kuibyshev reservoir coast. In: Natural Resources of the Volga-Kama Region. Issue 2. Publishing House of Kazan State University, Kazan.

Smirnova MI. 1970. Biocoenotic connections of some vertebrate animals helminths on the coast of the Kuibyshev reservoir. [Dissertation]. Kazan State University, Kazan, USSR.

Smirnova MI, Gorshkov PK, Sizova VG. 1987. Helminth fauna of tailless amphibians in Tatarstan Republic. Institute of Biology of Academy of
Sciences of the USSR. 19 p. Chief department of VINITI, № 8067B87.

Smirnova MI, Sizova VG. 1978. Helminth fauna of aquatic amphibians of the green zone of Kazan city. In: Natural Resources of the VolgaKama Region. Issue 5. Publishing House of Kazan State University, Kazan.

Sudarikov VE. 1959. Biological features of trematodes of the genus Alaria. Pap Helminthol Lab USSR Acad Sci 11: 326-332.

Sudarikov VE. 1960a. Order Strigeidida (La Rue, 1926) Sudarikov, 1959. In: Skryabin KI (ed.), Trematodes of animals and humans. Bases of trematodology. Vol 17. Part 2. Publ. USSR Academy of Sciences, Moscow.

Sudarikov VE. 1960b. Suborder Strigeata La Rue, 1926. Superfamily Diplostomatoidea Nicoll, 1937. In: Skryabin KI ed, Trematodes of animals and humans. Basis of trematodology. Vol 18. Publ. USSR Academy of Sciences, Moscow.

Sudarikov VE, Lomakin VV, Semenova NN. 1991. The trematode Pharyngostomum cordatum (Alariidae, Hall et Wigdor, 1918) and its life cycle under the conditions of the Volga delta. Pap Helminthol Lab USSR Acad Sci 38: 142-147.

Sudarikov VE, Shigin AA, Kurochkin YV, Lomakin VV, Stenko RP, Yurlova NI. 2002. Metacercariae of trematodes: parasites of freshwater aquatic organisms in Central Russia. Metacercariae trematodes: parasites of aquatic organisms in Russia. Vol 1. Nauka Publ, Moscow.

Tkach VV, Grabda-Kazubska B, Pawlowski J, Swiderski Z. 1999. Molecular and morphological evidence for close phylogenetic affinities of the genera Macrodera, Leptophallus, Metaleptophallus and Paralepoderma (Digenea, Plagiorchiata). Acta Parasitol 44: 170179.

Tkach VV, Pawlowski J, Mariaux J. 2000. Phylogenetic analysis of the suborder Plagiorchiata (Platyhelminthes, Digenea) based on partial 28S rDNA sequences. Intl J Parasitol 30: 83-93.

Tkach VV, Pawlowski J, Mariaux J, Swiderski Z. 2001. Molecular phylogeny of the suborder Plagiorchiata and its position in the system of Digenea. In: Littlewood DTJ, Bray RA (eds) Interrelations of the Platyhelminthes. Taylor \& Francis, London.

Vojtkova L. 1974. Motolice obojzivelniku CSSR. I. Dospele motolice. Folia Fac Sci Nat Univ Purk Brun Biol 25 (4): 1-133.

Vojtkova L, Roca V. 1994. Parasites of the frogs and toads in Europe. Part II: Trematoda. Rev Esp Herp 8: 7-18.

Vojtkova L, Vojtek J. 1975. Motolice obojzivelniku CSSR. II. Larvalni stadia. III. Trematodofauna jednotlivych druhu hostitelu. Folia Fac Sci Nat Univ Purk Brun Biol 16 (2): 1-87.

Volgar-Pastukhova LG. 1959. Helminth fauna of anurans in the Danube delta. Ecological parasitology. Leningrad State University, Leningrad.

Yumagulova GR. 2000. Helminths of amphibians of the Southern Urals. [Dissertation]. Bashkir State Agricultural University, Ufa. [Russia] 